Article

\title{
Integration of Policy Decision Making for Sustainable Land Use within Cities
}

\author{
Soyoung Kim
}

Citation: Kim, S. Integration of Policy Decision Making for Sustainable Land Use within Cities. Sustainability 2021, 13, 10390. https://doi.org/10.3390/su131810390

Academic Editor: George

D. Bathrellos

Received: 5 August 2021

Accepted: 11 September 2021

Published: 17 September 2021

Publisher's Note: MDPI stays neutral with regard to jurisdictional claims in published maps and institutional affiliations.

Copyright: (C) 2021 by the author. Licensee MDPI, Basel, Switzerland. This article is an open access article distributed under the terms and conditions of the Creative Commons Attribution (CC BY) license (https:/ / creativecommons.org/licenses/by/ $4.0 /)$.
School of Liberal Arts, Seoul National University of Science and Technology, Seoul 01811, Korea; soyoung.kim@seoultech.ac.kr; Tel.: +82-2-970-6786

\begin{abstract}
Local land use policies can shape the sustainability of urban systems, but integrated land use at the local level is challenging since it requires the coordination of multiple semi-independent agencies within cities to effectively address collective actions problems and overcome functional divisions. Although this problem is widely acknowledged, systematic examination of what factors are related to internal coordination of land use functions is lacking. This research investigates what influences the extent to which cities coordinate across functional areas to promote integrative land use decision making. I address this question by first describing a conceptual framework drawing from institutional collective action (ICA) perspectives to understand internal city collaboration across policy functions. I then advance explanations linking institutions and community characteristics to the degree of coordination in municipal land use. Using a 2015 survey of 1124 U.S. cities, I test the hypothesized relationships based on the functional institutional collective action framework. The findings reveal that political institutions, city operation of utilities, elected officials support, and fiscal capacity increase coordination. In conclusion the implications of the findings for theory and land use planning research are discussed.
\end{abstract}

Keywords: institutional collective action; functional collective action; policy integration; local government; policy coordination; institutions; local governance

\section{Introduction}

Problems of fragmentation and cross-functional coordination are long-standing concerns for local governments [1,2]. Coordination across policy functions is particularly problematic for land use. Land use planning is a key local government activity, which includes long-range land use policy, growth management, regulatory planning, and implementation. Land use decisions are described as central to economic development "growth machine" $[3,4]$ as well as to sustainability $[5,6]$. It generally involves defining appropriate types and forms of land uses, as well as providing infrastructure and open space for efficient and sustainable utilization of land in order to provide benefits to the broader population, the economy, and the environment.

A robust literature has studied intergovernmental fragmentation and the problem of integration or coordination across governments [7-10]. By contrast little attention has been given to how to integrate functionally fragmented responsibilities within governments, and no previous studies have examined the administrative integration of land use decisions.

Land use, like other complex and crosscutting issues, requires the cooperation of multiple semi-independent units in order to effectively address collective action problems and overcome functional divides. Local land use policies have been demonstrated to shape the sustainability of urban systems through integrated planning, management, and governance [11]. For example, interviews with local governments officials in Canada found that strong collaboration was necessary to integrate local government departments or functional areas and enhance long-term land use planning and asset management [12].

Since sustainable land use planning cross-cuts multiple functional and policy issue areas, local governments must consider the political and administrative nature and ap- 
plications of their actions. From a political standpoint, land use issues require solutions that transcend political-administrative boundaries. Local agencies must communicate and negotiate to find ways to address problems of the commons [10,13,14], even though the functions are administratively siloed [15-19]. In US local governments, economic development, land use planning and permitting, environmental protection, climate change mitigation, climate change adaptation and open space and farmland preservation are typically the responsibility of separate municipal government departments or agencies.

The network governance and institutional collective action (ICA) literatures articulate how integration across multiple authorities and venues $[20,21]$ operates as a mechanisms to mitigate the fragmentation of public authority. ICA argues that interorganizational coordination across policy functions, reflects a collective action problem since the ability to achieve jurisdiction-wide collective benefits depends on the efforts and contributions of the agencies responsible for the necessary services. The nature of the policy, the interests of the agencies involved, and the local institutions in place determine whether coordination is risky [22-24]. Collaboration risk occurs because agencies give up some autonomy and must devote time and resources to the collective activity, but success depends on the contributions of other agencies [15,25]. Land use offers an ideal lens through which to study this type of functional collective action dilemma and how they are overcome [26-30]. The ICA framework $[15,19,25]$ identifies certain factors that can stimulate cross-function coordination and lead to both more and more targeted policy actions $[17,18]$. Despite wide recognition fragmentation problems and administrative silos, systematic studies to examine what factors are related to integration of decision making are rare, and examination of land use coordination is conspicuously absent from the literature.

This research begins to fill this lacuna by asking: What factors influence land use coordination across functional areas to promote integrative land use decision making? I address this question by first describing a conceptual framework drawing from the institutional collective action (ICA) framework to understand internal city collaboration across functional departments. I then advance hypotheses linking community characteristics and institutions to the degree of degree of functional coordination. Four factors are hypothesized to stimulate internal coordination of land use within cities: professional public management institutions, electoral support, municipal fiscal capacity, and the extent to of cities exercise control over local infrastructure systems through municipal utilities. Using a 2015 survey of 1124 U.S. cities, I test these hypotheses. The findings support the ICA explanation, but they also suggest that the barriers and facilitators of integrated land use decisions differ from those for other policy arenas and levels of government Governmental institutions, resources and municipal utilities were each found to play critical roles in land use coordination.

\subsection{Institutional Collective Action Framework}

The ICA framework offers a general model of collaboration among public organizations that focuses on collective action problems in the production of public goods [15,19]. The ICA framework identifies mechanisms mitigate horizontal, vertical, and functional collective action problems that arise from fragmented authority that characterize a federalist system $[16,22,23]$. Horizontal dilemmas occur from the spatial mismatch between problems and the governments with authority to address the problems. When the jurisdictional boundaries of governments units are too small to individually solve the problem, then spillovers, diseconomies of scale and free-rider problems result. Thus, collective action among multiple governments is necessary to address collective problems. Vertical ICA dilemmas arise when different levels of government pursue similar or overlapping policy objectives. Functional ICA dilemmas are defined by the connectedness of services, policies, and resource systems. Fragmentation of policy making and administrative responsibilities for land use within municipal governments functional collective action dilemmas that are different from vertical and horizontal dilemmas focused on intergovernmental relationships since they are a product of functional fragmentation of authority among 
departments and agencies within a single government $[13,16]$. While substantial research been undertaken to test the propositions of the framework for horizontal and vertical ICA dilemmas, much less is known about functional ICA [14].

A key dimension of coordination to mitigate functional ICA dilemmas is the scope of policies that they encompass. Although coordination across a broader and more expansive portfolio of policy functions can improve outcomes [31], it also imposes transaction costs on individual agencies that give up some autonomy by coordinating their actions with other agencies [14]. The ICA framework presumes that local governments, or functional agencies within a local government will seek to collaborate when the utility of doing so outweighs the benefits of operating independently and pursing an agency-specific not a city-wide agenda.

Drawing from research on horizontal policy coordination across cities [15,18,19], I hypothesize that four governmental factors will stimulate internal coordination of land use among agencies within cities: professional public management institutions, city control over utilities governing local infrastructure systems, electoral support, and municipal fiscal capacity.

\subsubsection{Professional Management Institutions}

Peters [2] offers a rich description of administrative coordination issues and suggests that the institutions of governance influence integration across programs. At the municipal level in the US, form of government-typically either mayor-council structure with an elected mayor as a chief executive or a council-manager structure in which a professional manager hired by the elected council-is fundamental to the structure and operation of city governments [32]. Mayor/council cities divide political authority between elected executive and legislative branches of government, but council-manager governments consolidate political power in a single branch and the city council collectively hires a professional administrator to manage city operations. Thus, I hypothesize that cities with professionalized council-manager form of government coordinate a greater number of land use functions.

\subsubsection{Electoral Support}

Support, or at least a lack of opposition to the city's land use sustainability policy goals, is anticipated to be important for coordination by reinforcing the city commitment to collective land use sustainability goals. Opposition from elected leaders might can produce conflicting strategies and can also provide an ally to agencies seeking to act purse agency level agenda and insulate agencies that protect their own autonomy. Such an effect is consistent with the ICA framing and findings regarding policy coordination across cities. Thus, I hypothesize that cities in which local officials do not support community sustainability goals will coordinate a smaller number of land use functions.

\subsubsection{Fiscal Capacity}

Studies of economic development in large cities report that higher population cities with greater fiscal resources have more centralized and integrated development policies [33,34]. Resource capacity can advantage efforts to integrate land use policy decision making. However, greater fiscal and technical capacity might also make individual agencies more independent and protective of their autonomy. General government capacity effects are controlled by per capita tax revenue generated from general municipal sales and municipal property taxes. I hypothesize that cities with strong fiscal capacity coordinate a greater number of land use functions.

\subsubsection{Municipal Utilities}

Municipal infrastructure systems can link municipal policies, programs, and functions as instruments for city wide sustainable and efficient land use. Municipal utilities are recognized as a valuable tool in supporting local and regional economic develop- 
ment. Recent research suggests utilities also play and important role in sustainability as well [33,35-38]. Since infrastructure systems overlap and connect, many local government services and functions, city government control over energy, water, waste management and other utilities is anticipated to promote more integrated land use decision making. Municipal utility operations, with their vested interests in sustainability outcomes, along with their well-endowed resources offer mechanisms for coordinating the actions of functional departments of the city. Their connections and resources position them to guide decentralized efforts through their institutional leverage and capacity to coordinate relevant functions spread across semi-autonomous units. Thus, utilities have the potential to play an integrative policy role. I hypothesize that cities operating more municipal utilities coordinate a greater number of land use functions. The ICA literature also suggests that population, density race and income need to be accounted for.

\section{Materials and Methods}

This study examines functional collective action efforts for sustainability actions in 1124 U.S. cities. The respondents are representative of the population of all cities in the US in terms of region, population size, racial composition, and income. The only significant variation was that the northeast region of the country was underrepresented in the sample. Data for this analysis come from a sample of cities with populations over 2500 that responded to the International City/County Management Association's (ICMA) 2015 Survey on Local Government Sustainability Practices. The survey sample for this study consists of cities and counties was drawn from local governments reporting financial data within the U.S. Census of Governments 2012. The survey was administered in paper format via direct mail, with an online submission option. The survey was sent to 8562 city and county governments and achieved a response rate of $22.2 \%$, with 1899 local governments responding including 1124 cities.

\subsection{Dependent Variable}

The ICMA surveyed municipalities regarding whether "the departments in your jurisdiction coordinate on the following programs or policies" The land use related policies include: economic development, land use planning/permitting, environmental protection, climate change mitigation, climate change adaptation, open space/farmland preservation. Table 1 displays the specific land use policy areas used within the indices. The percentage values within the table display the percent of "yes" versus "no" responses for individual policies. As shown below, the categories of planning and permitting, economic development and environmental protection have higher frequencies of coordination while open space preservation, climate mitigation, and climate adaption activities exhibit lesser frequencies of coordination.

Table 1. Coordination of Policy Areas within Cities.

\begin{tabular}{ccc}
\hline Policy Area & Frequency & Percent Yes \\
\hline Land use permitting & 1041 & 92.6 \\
Economic development & 989 & 88.0 \\
Environmental protection & 688 & 61.2 \\
Open space preservation & 494 & 44.0 \\
Climate mitigation & 148 & 13.2 \\
Climate change adaptation & 106 & 9.4 \\
\hline
\end{tabular}

I construct an additive index variable for functional coordination on land use across specific land use policy areas to capture functional integration. Table 2 reports the distribution of the land use functional coordination index scores. This index has a Cronbach's alpha of 0.641 and a mean of 3.08, offering support for the additive index of functional ICA. Most cities had coordinated sustainable land use actions across departments in 2-4 policy areas. Auxiliary principal components analysis reports that all six variables load on a single factor 
with an eigen value of 3.85 , adding further support for the validity of the additive index in capturing the level of functional collective action.

Table 2. Index of Land Use Coordination.

\begin{tabular}{cc}
\hline Coordination Index & Percent \\
\hline 0 & 4.0 \\
1 & 5.7 \\
2 & 21.7 \\
3 & 32.0 \\
4 & 25.7 \\
5 & 4.8 \\
6 & 6.0 \\
\hline Total & 100.0 \\
\hline Mean $=3.083$ 3.08. Std. Deviation 1339. Nof Items 6. Cronbach' Alpha 0.641.
\end{tabular}

Mean $=3.08$ 3.08. Std. Deviation 1.339. $\mathrm{N}$ of Items 6. Cronbach' Alpha 0.641.

\subsection{Independent Variables}

Professional Management Institutions. Political institutional effects are captured by whether the city operates under a council manager form of government. Council-manager government is measured with a dummy variable indicating whether a city had the councilmanager form of government in place in 2015.

Electoral Support. A lack of support from elected leaders can provide opportunities for agencies seeking to purse their own agency-level interests rather than city-level interest, thus impeding coordination [13,22]. For this reason, I include a survey indicator of electoral opposition to sustainability goals. Survey respondents were asked about the extent to which opposition from elected officials was hindering sustainability efforts in their local government on a four-point Likert scale.

Fiscal Capacity. Capacity is reflected in governmental revenue resource availability. The measure of fiscal capacity is the per-capita tax revenue generated from general municipal sales and municipal property taxes in 2015.

Municipal Utilities. Municipal utility ownership is used to measure the levels of municipal responsibility for utility operations. The ICMA survey included questions that asked respondents if their municipality owned a utility operation across seven types of utility functions: electricity, storm water, gas, water, district heating, wastewater, and communications. I use these functions to create an additive index, denoting the scope of municipal involvement in utility operations. A higher value on the index denotes greater involvement in municipal operations.

\subsection{Control Variables}

The analyses also control for city characteristics that have been linked to either intergovernmental or intragovernmental collaborations. I use the natural log of the population to measure a jurisdiction's service demand. The variable population density is calculated as the ratio of the population per square mile and captures the effects of urbanization. Demographic diversity and economic need are added because they have been found to make policy coordination more difficult [17]. I measure the percent of the population White non-Hispanic and the percent of the population between the ages of 25 and 44 . and the median property value in thousands to capture sustainability service market effects. The variable descriptions, measures and sources for all explanatory variables are reported in Table 3. 
Table 3. Descriptive Statistics for Predictor Variables.

\begin{tabular}{lcccc}
\hline & Mean/Prop. & S.D. & Minimum & Maximum \\
\hline ICA Explanatory Variables & & & & \\
Council manager & 0.674 & 0.469 & 0 & 1 \\
Municipal utility ownership & 2.135 & 1.274 & 0 & 6 \\
Electoral opposition & 1.501 & 1.093 & 0 & 3 \\
Per capita own-source revenue & 0.623 & 0.536 & 0.001 & 5.62 \\
Controls & & & & \\
Population logged & 9.722 & 1.256 & 7.75 & 15.15 \\
Population density & 2381.2 & 1990.1 & 99.49 & $16,443.3$ \\
Percent White non-Hispanic & 0.798 & 0.171 & 0.057 & 1.00 \\
Median household income & 54,651 & 24,102 & 16,528 & 237,135 \\
\hline Note: $N=1124$ observations. & & & &
\end{tabular}

Note: $N=1124$ observations.

\section{Results}

I test the ICA explanations for municipal land use coordination by estimating a linear regression on the index of land use functional coordination. The regression analysis includes the measures to test the four hypotheses drawn from the ICA framework as presented in earlier section. The control variables are included in the estimations as well. Regression estimates are reported in Table 4.

Table 4. ICA Explanation for Land Use Integration.

\begin{tabular}{lccc}
\hline \multicolumn{1}{c}{ Variable } & B & Std. Error & $t$ Value \\
\hline (Constant) & -1.464 & 0.406 & -3.602 \\
council manager government & 0.188 & 0.078 & 2.397 \\
municipal owned utilities & 0.157 & 0.030 & 5.184 \\
Opposition of elected officials & -0.036 & 0.014 & -2.639 \\
Per capita own-source revenues & 0.030 & 0.007 & 4.306 \\
natural log of population & 0.340 & 0.033 & 10.343 \\
White non-Hispanic percent & 0.179 & 0.234 & 0.764 \\
population density & 0.000052 & 0.000 & 2.571 \\
Median household income & 0.000006 & 0.000 & 4.028 \\
\hline
\end{tabular}

F= 37.4; sig. 0.000 .

The regression results offer support for each of the four hypotheses. Councilmanager form of government, municipal utility ownership and per-capita revenues were each positively related to land use coordination, while opposition to sustainability goals among elected officials was negatively related to integration as predicted. The coefficients were sizable and statistically significant at 0.01 levels. In addition to the positive effect of council-manager government, greater opposition to sustainability goals on the part of local government elected officials had a negative impact on coordination. The fiscal capacity of local government was positively related to the scope of land use coordination. The greater the number of municipal owned utilities, the more land use functions coordinated.

\section{Discussion}

There are increasing calls for policy integration at a time when land use decisionmaking is facing increasing complexity. Although the issue of policy integration is receiving increased attention in the literature [33,34,38-42], systematic studies of what factors support or impede policy integration have been few and far between. While integration is seen as a desirable objective, understanding what exactly it means and what factors facilitate its achievement are limited [18,42-44]. Since coordination across departments and agencies of government is critical to addressing complex issues of planning, development, and sustainability, the ICA framework can advance understanding of variation in cities in their 
ability to integrate land use decisions and to overcome limitations such as constrained capacity and limited authority [45-47].

I first investigated the role of local institutions by testing whether cities with council manager government coordinated a larger set of land use institutions. Although studies of policy coordination and collaboration at the city level link institutions to cross-city collaborations, analysis at the functional level is sparce [15-17] and no previous work examines functional coordination for land use. The analysis confirms the hypothesis that cities with council-manager form of government coordinate a greater number of land use functions. Cities with professional management institutions have a significantly greater scope of land use coordination that cities with mayor council governments. This may reflect the emphasis on city-wide orientation of city managers $[30,31]$ and their focus on organizational efficiency [32,48].

I also found that local official's opposition to sustainability goals was related to less functional coordination. In city-level research, officials support or opposition to sustainability goals has been a predictor of climate and environmental policy adoptions and collaboration among governments implementing those policies $[49,50]$. Political support reinforces city commitment to collective land use sustainability while opposition from elected leaders might can produce conflicting strategies and the opportunity city agencies to act purse their agency-level priorities. It can also insulate agencies from pressure to collaborate, so they protect their own autonomy. The hypothesized relationship seems straightforward, but it has had mixed support for city level horizontal coordination [14]. Consistent with the ICA framework, the results at the functional level demonstrate that cities in which local officials do not support community sustainability goals will coordinate a smaller number of land use functions.

The hypothesis linking city fiscal capacity to functional collaboration was strongly supported in the analysis. Previous studies report that fiscal capacity increases the likelihood that cities engage with neighboring communities in array of land use programs and actions [31,32], but in some cases the relationship is negative rather than positive [51]. This is attributed to the fact that cities with strong fiscal health may be able to carry out complex and large-scale policy on their own and do not need to collaborate with others [51]. But if this is the case, then fiscally strong cities "going it alone" would have a high need for internal coordination.

Municipal infrastructure systems can link municipal policies, programs, and functions as an instrument for city wide sustainable and efficient land use. Utilities support local and regional economic development and sustainability as well [35-37]. Since infrastructure systems overlap and connect, many local government services and functions they can play an integrative policy role.

Despite the potential role of municipal utilities in policy coordination, there is little research examining their effect on coordination among cities or functions. Except the recent work of Farmer [52,53] coordination among cities has not been studied, and empirical studies of functional collaboration are absent. The analysis provides support for the hypothesize that cities operating more municipal utilities coordinate a greater number of land use functions.

\section{Conclusions}

This paper investigated what factors influence the degree to which land use decisions in local governments are functionally coordinated. Based on the ICA framework and empirical work examining policy coordination between cities, hypotheses were advanced and tested though a national survey of US cities. Regression results indicate that internal coordination of land use within cities is related to professional public management institutions, electoral support, municipal fiscal capacity, and control over municipal utilities. The findings reported here confirm the ICA explanation, but they also suggest that the barriers and facilitators of integrated land use decisions differ from those for horizontal policy coordination across local governments. 
Future research might use the framework here to structure case analysis that would focus on the causal mechanisms and the sensitivity of land use coordination to institutional and political change. Future work might also examine the robustness of the ICA framework for explaining functional forms of institutional collective action outside of the US. Studies of horizontal ICA have appeared in Asia [23,45,54-56] Latin America [22,49] and Europe $[25,26,42,46]$. To date the only studies of functional ICA outside the US are in China $[15,16,54-56]$. This promising work suggest the robustness of the framework, but future work in other countries and contexts is needed to draw more definitive conclusions.

Funding: This work was supported by the Ministry of Education of the Republic of Korea and the National Research Foundation of Korea (NRF-2020S1A5A2A03046573).

Institutional Review Board Statement: Not applicable.

Informed Consent Statement: Not applicable.

Data Availability Statement: Data available through the International City and County Management Association.

Conflicts of Interest: The authors declare no conflict of interest.

\section{References}

1. Kaufman, H. The Forest Ranger: A Study of Administrative Behavior; Johns Hopkins Press: Baltimore, MD, USA, 1960.

2. Peters, B.G.; Pierre, J. Governance without government? Rethinking public administration. J. Public Adm. Res. Theory 1998, 8 , 223-244. [CrossRef]

3. Molotch, H. The city as a growth machine: Toward a political economy of place. Am. J. Sociol. 1976, 82, 309-332. [CrossRef]

4. Stone, C. Regime Politics: Governing Atlanta 1946-1988; University Press of Kansas: Lawrence, KS, USA, 1989.

5. Berry, J.; Portney, K. Sustainability and Interest Group Participation in City Politics. Sustainability 2013, 5, 2077-2097. [CrossRef]

6. Ostrom, V.; Bish, R.L.; Ostrom, E. Local Government in the United States; ICS Press: San Francisco, CA, USA, 1988.

7. Feiock, R.C. Metropolitan Governance: Conflict, Competition, and Cooperation; Georgetown University Press: Washington, DC, USA, 2004.

8. Feiock, R.C.; Lee, I.; Park, H.; Lee, K. Collaboration networks among local elected officials: Information, commitment, and risk aversion. Urban Aff. Rev. 2010, 47, 241-262. [CrossRef]

9. Kwon, S.W.; Feiock, R.C.; Bae, J. The roles of regional organizations in interlocal resource exchange: Complement or substitute? Am. Rev. Public Adm. 2014, 44, 339-357.

10. Liu, J.; Hull, V.; Godfray, H.C.; Tilman, D.; Gleick, P.; Hoff, H.; Pahl-Wostl, C.; Xu, Z.; Chung, M.G.; Sun, J.; et al. Nexus approaches to global sustainable development. Nat. Sustain. 2018, 1, 466-476. [CrossRef]

11. Fowler, K. Local Government Land Use and Asset Management Planning in BC. 2019. Available online: http:// sustainabilitymakescents.com/downloads/kim_fowler-municipal-land-use-planning-asset-management-bc.pdf (accessed on 12 January 2021).

12. Ostrom, E. Governing the Commons; Cambridge University Press: Cambridge, UK, 1990.

13. Feiock, R.C. The institutional collective action framework. Policy Stud. J. 2013, 41, 397-425. [CrossRef]

14. Feiock, R.C.; Scholz, J. Self-Organizing Federalism: Collaborative Mechanisms to Mitigate Institutional Collective Action Dilemmas; Cambridge University Press: New York, NY, USA, 2010.

15. Yi, H.; Huang, C.; Chen, T.; Xu, X.; Liu, W. Multi-level environmental governance: Vertical and horizontal influences in local policy networks. Sustainability 2019, 11, 2390. [CrossRef]

16. Yi, H.; Cui, C. Coping with functional collective action dilemma: Functional fragmentation and administrative integration. Public Manag. Rev. 2019, 21, 1052-1075. [CrossRef]

17. Feiock, R.C.; Krause, R.; Hawkins, C. The impact of administrative structure on the ability of city governments to overcome functional collective action dilemmas. J. Public Adm. Res. Theory 2017, 27, 615-628. [CrossRef]

18. Kim, S.; Swann, W.; Weible, C.; Bolognesi, T.; Krause, R.; Park, A.; Tang, T.; Maletsky, K.; Feiock, R.C. Updating the institutional collective action framework. Policy Stud. J. 2020. [CrossRef]

19. Andrew, S.A.; Kendra, J.M. Regional integration through agreements: Does multiplexity in urban service deliveries matter? Presented at the Workshop on the Workshop 4, Bloomington, IN, USA, 3-6 June 2009.

20. Lubell, M.N. Governing institutional complexity: The ecology of games framework. Policy Stud. J. 2013, 41, 537-559. [CrossRef]

21. Feiock, R.C.; Portney, K.E.; Bae, J.; Berry, J.M. Governing local sustainability. Urban Aff. Rev. 2014, 50, 157-179. [CrossRef]

22. Ramirez de la Cruz, E.E. Local political institutions and smart growth: An empirical study of the politics of compact development. Urban Aff. Rev. 2009, 45, 218-246. [CrossRef] 
23. Jung, K.; Song, M.; Park, H.J. The dynamics of an interorganizational emergency management network: Interdependent and independent risk hypotheses. Public Adm. Rev. 2019, 79, 225-235. [CrossRef]

24. Kettl, D.F. Sharing Power: Public Governance and Private Markets; The Brookings Institution: Washington, DC, USA, 2009.

25. Rodrigues, M.; Tavares, A.F.; Araújo, J.F. Municipal service delivery: The role of transaction costs in the choice between alternative governance mechanisms. Local Gov. Stud. 2012, 38, 615-638. [CrossRef]

26. Tavares, A.F.; Camões, P.J. New forms of local governance. Public Manag. Rev. 2010, 12, 587-608. [CrossRef]

27. Shrestha, M.; Berardo, R.; Feiock, R.C. Solving institutional collective action problems in multiplex networks. Complex. Gov. Netw. 2014, 1, 49-60.

28. Terman, J.N.; Feiock, R.C.; Youm, J. When collaboration is risky business: The influence of collaboration risks on formal and informal collaboration. Am. Rev. Public Adm. 2019, 50, 33-44. [CrossRef]

29. Miller, D.Y.; Nelles, J. Discovering American Regionalism: An Introduction to Regional Intergovernmental Organizations; Routledge: New York, NY, USA, 2017.

30. Carr, J.B.; Karuppusamy, S. Beyond ideal types of municipal structure: Adapted cities in Michigan. Am. Rev. Public Adm. 2009, 39, 304-321. [CrossRef]

31. Sharp, E.B. The politics and economics of the new city debt. Am. Polit. Sci. Rev. 1986, 80, 1271-1288. [CrossRef]

32. Bae, J.; Feiock, R.C. Forms of government and climate change policies in US cities. Urban Stud. 2013, 50, 776-788. [CrossRef]

33. Homsy, G.C. Capacity, sustainability, and the community benefits of municipal utility ownership in the United States. J. Econ. Policy Reform 2020, 23, 120-137. [CrossRef]

34. Fleischmann, A.; Green, G.P. Organizing local agencies to promote economic development. Am. Rev. Public Adm. 1991, 21, 1-15. [CrossRef]

35. Park, J.; Feiock, R.C. Stability and change in county economic development organizations. Econ. Dev. Q. 2012, 26, 3-12. [CrossRef]

36. Stead, D.; Meijers, E. Policy integration in practice: Some experiences of integrating transport, land-use planning and environmental policies in local government. In Proceedings of the Berlin Conference on the Human Dimensions of Global Environmental Change: Greening of Policies-Interlinkages and Policy Integration, Berlin, Germany, 3-4 December 2004; Available online: http:/ / userpage.fu-berlin.de/ffu/akumwelt/bc2004/download/stead_meijers_f.pdf (accessed on 15 January 2021).

37. Selman, P.H.; Barker, A.J. Rural land use policy at the local level: Mechanisms for collaboration. Land Use Policy 1989, 6, 281-294. [CrossRef]

38. Andrew, S.A. Regional integration through contracting networks, Urban colloquy: Regional governance and the problem of institutional collective action. Urban Aff. Rev. 2009, 44, 378-402. [CrossRef]

39. Terman, J.N.; Feiock, R.C. Improving outcomes in fiscal federalism: Local political leadership and administrative capacity. J. Public Adm. Res. Theory 2014, 25, 1059-1080. [CrossRef]

40. Gerber, E.; Loh, C.G. Spatial dynamics of vertical and horizontal intergovernmental collaboration. J. Urban Aff. 2015, 37, 270-288. [CrossRef]

41. Gerber, E.; Henry, A.; Lubell, M. Political Homophily and Collaboration in Regional Planning Networks. Am. J. Polit. Sci. 2013, 57, 598-610. [CrossRef]

42. Szmigiel-Rawska, K.; Dabrowska, A. Pride and prejudice: The local leaders' attitude towards place-based collaboration in the Warsaw metropolitan area. Lex Localis-J. Local Self-Gov. 2016, 14, 827-851. [CrossRef]

43. Lee, H. Functional collective action dilemma and collaborative management. In Handbook of Collaborative Public Management; Meek, J., Ed.; Edward Elgar: Cheltenham, UK, 2021.

44. Deslatte, A.; Stokan, E. Sustainability Synergies or Silos? The Opportunity Costs of Local Government Organizational Capabilities. Public Adm. Rev. 2020, 80, 1024-1034. [CrossRef]

45. Song, M. Testing the forms and consequences of collaboration risk in emergency management networks. Soc. Sci. J. 2020. [CrossRef]

46. Camões, P.; Tavares, A.; Teles, F. Assessing the intensity of cooperation: A study of joint delegation of municipal functions to inter-municipal associations. Local Gov. Stud. 2021, 47, 593-615. [CrossRef]

47. Kwon, S.; Park, S. Metropolitan governance: How regional organizations influence interlocal land use coordination. J. Urban Aff. 2014, 36, 925-940. [CrossRef]

48. Carr, J.B. What have we learned about the performance of council-manager government? A review and synthesis of the research. Public Adm. Rev. 2015, 75, 673-689. [CrossRef]

49. Meza, O.; Grin, E.; Fernandes, A.; Abrucio, F. Intermunicipal cooperation in metropolitan regions in brazil and Mexico: Does federalism matter? Urban Aff. Rev. 2019, 55, 887-922. [CrossRef]

50. Swann, W.; Kim, S. Practical prescriptions for governing fragmented governments. Policy Polit. 2018, 46, 273-292. [CrossRef]

51. Hawkins, C.; Krause, R.; Curley, C. Making meaningful commitments: Accounting for variation in cities' investments of staff and fiscal resources to sustainability. Urban Stud. 2016, 53, 1902-1924. [CrossRef]

52. Farmer, J. Municipal utilities and local sustainability efforts: Horizontal and vertical impacts. Univ. Nev. Las Vegas 2022, unpublished.

53. Farmer, J. The Roles of Utility Districts and Institutional Embeddedness in Regional Partnerships for Climate Change Mitigation. 2021. Available online: https:/ / www.researchgate.net/publication/349710320 (accessed on 15 July 2021). 
54. Chen, S. The Institutional Collective Action Framework: An Application to Regional Governance in Taiwan, Working Paper. 2017. Available online: http://www.amalgamationyes.ca/uploads/2/7/4/7/27470281/institutional_collective_action_framework.pdf (accessed on 16 July 2021).

55. Shaowei, C.; Rui, L.; Youqiang, W. Role and significance of political incentives: Understanding institutional collective action in local inter-governmental arrangements in China. Asia Pac. J. Public Adm. 2016, 38, 211-222. [CrossRef]

56. Liu, Y.; Wu, J.; Yi, K.; Wen, J. Under what conditions do governments collaborate? A qualitative comparative analysis of air pollution control in China. Public Manag. Rev. 2021, 1-19. [CrossRef] 